\title{
Reduced duration of muscle relaxation with rocuronium in a normocalcemic hyperparathyroid patient
}

\author{
[Relâchement musculaire de durée réduite avec le rocuronium chez un patient \\ normocalcémique présentant une hyperparathyrö̈die]
}

Muhammad A. Munir MD, Muhammad Jaffar MD FCCP, Muhammad Arshad MD, M. Shahab Akhter MD, Junming Zhang MS MD

Purpose: To report a case of reduced duration of action of rocuronium in a patient with normocalcemic hyperparathyroidism (HPT).

Clinical features: A 56-yr-old patient with primary HPT, who had had surgical resection of three and a half parathyroid glands nine months previously, was referred to our institution for further investigation of a persistent increase in parathyroid hormone. Preoperatively, the patient had a normal serum ionized and total calcium. The patient was diagnosed with a persistent parathyroid adenoma and was scheduled for an elective parathyroidectomy.

General anesthesia was induced with iv propofol, fentanyl and succinylcholine. Intraoperatively, anesthesia was maintained with nitrous oxide in oxygen, and isoflurane. Neuromuscular blockade was attained using incremental doses of rocuronium. The average duration of $0.15 \mathrm{mg} \cdot \mathrm{kg}^{-1}$ incremental doses of rocuronium was 5.9 min (expected: 13-18 min), and that of $0.2 \mathrm{mg} \cdot \mathrm{kg}^{-1}$ was ten minutes (expected: 19-23 min).

Conclusion: Primary HPT even in the absence of hypercalcemia may result in resistance to competitive blockade by rocuronium. It suggests that primary HPT may cause acetylcholine receptor upregulation resulting in hyposensitivity to non-depolarizing muscle relaxants.

Objectif : Présenter un cas de réduction du temps d'action du rocuronium chez un patient atteint d'hyperparathyroïdie (HPT) normocalcémique.

Éléments cliniques : Un patient de 56 ans, atteint d'HPT primaire, avait subi, neuf mois auparavant, la résection chirurgicale de trois glandes parathyroïdes et demie et avait été dirigé vers notre institution pour une investigation plus poussée de l'augmentation persistante de l'hormone parathyroïde. Avant l'opération, le patient avait un niveau de calcium total et ionisé normal. Le diagnostic d'adénome parathyroïde persistant a été établi et une parathyroïdectomie a été planifiée. L'anesthésie générale a été induite avec des agents iv, propofol, fentanyl et succinylcholine. Pendant l'opération, l'anesthésie a été maintenue avec du protoxyde d'azote dans de l'oxygène, et de l'isoflurane. Le blocage neuromusculaire a été obtenu par des doses progressives de rocuronium. La durée moyenne des doses progressives de 0,15 mg. $\mathrm{kg}^{\prime}$ a été de 5,9 min (normale: 13-18 min), et celle des doses de 0,2 $\mathrm{mg} \cdot \mathrm{kg}^{-1}$ a été de $10 \mathrm{~min}$ (normale : 19-23 min).

Conclusion : L'HPT primaire, même sans hypercalcémie, peut provoquer une résistance au blocage compétitif du rocuronium. Ce qui suggère que l'HPT primaire puisse causer une régulation positive du récepteur d'acétylcholine menant à une hyposensibilité aux myorelaxants non dépolarisants.

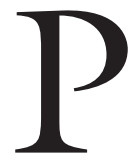

RIMARY hyperparathyroidism (HPT) is present when the serum level of parathyroid hormone (PTH) is increased due to (a) a benign parathyroid adenoma $(90 \%) ;(b)$ hyperplasia of the parathyroid glands $(9 \%)$; or (c) in rare cases, parathyroid carcinoma. ${ }^{1}$ It has been reported that primary HPT with hypercalcemia increases the requirement for non-depolarizing muscle relaxants (NDMRs). ${ }^{2,3}$ It has also been shown that hypercalcemia antagonizes the effects of NDMR. ${ }^{4}$ We report here a case in which a patient with primary HPT with normal serum calcium levels, after subtotal parathy-

From the Department of Anesthesiology, University of Arkansas for Medical Sciences, Little Rock, Arkansas, USA.

Address correspondence to: Dr. Muhammad A. Munir, Department of Anesthesiology, Slot 515,

University of Arkansas for Medical Sciences, Little Rock, AR 72205-7199, USA. Phone: 501-686-6114; Fax: 501-686-8139;

E-mail: munirmuhammada@uams.edu

Support was provided solely from institutional and/or departmental sources.

Accepted for publication January 28, 2003.

Revision accepted March 19, 2003. 
roidectomy nine months previously, had an abnormal response to rocuronium.

\section{Clinical report}

A 56 -yr-old, 90-kg, 162-cm Caucasian female, with a past medical history of primary HPT, who had had surgical resection of three and a half parathyroid glands nine months previously, was referred to our institution for further investigation of a persistent increase in PTH. Laboratory studies demonstrated serum total calcium of $10.8 \mathrm{mg} \cdot \mathrm{dL}^{-1}$ (normal range, $8.5-11.0 \mathrm{mg} \cdot \mathrm{dL}^{-1}$ ), serum ionized calcium of $5.1 \mathrm{mg} \cdot \mathrm{dL}^{-1}$ (normal range, $\left.4.5-5.5 \mathrm{mg} \cdot \mathrm{dL}^{-1}\right)$, serum phosphorus of $2.9 \mathrm{mg} \cdot \mathrm{dL}^{-1}$ (normal range, 2.5-4.5 $\mathrm{mg} \cdot \mathrm{dL}^{-1}$ ), and PTH level of $69.4 \mathrm{pg} \cdot \mathrm{mL}^{-1}$ (normal range, $10.0-65.0 \mathrm{pg} \cdot \mathrm{mL}^{-1}$ ). Serum electrolytes (sodium, chloride, potassium and magnesium $)$, serum creatinine $\left(0.6 \mathrm{mg} \cdot \mathrm{dL}^{-1}\right)$, coagulation profile, and liver function tests were all within normal limits.

Magnetic resonance imaging of the neck showed no evidence of residual or recurrent parathyroid tumour. However, a Technetium 99-M Sestamibi scan showed a persistent focus of increased uptake inferior to the left lobe of the thyroid, consistent with a parathyroid adenoma. The patient was diagnosed with a persistent parathyroid adenoma and was scheduled for elective parathyroidectomy.

On the morning of surgery, the patient was premedicated with $2 \mathrm{mg}$ of iv midazolam. After placement of standard monitors and preoxygenation, general anesthesia was induced intravenously with 2.5 $\mathrm{mg} \cdot \mathrm{kg}^{-1}$ of propofol, $\mathrm{l} \mu \mathrm{gg} \cdot \mathrm{kg}^{-1}$ of fentanyl and 1.5 $\mathrm{mg} \cdot \mathrm{kg}^{-1}$ of succinylcholine (SCh). The patient's trachea was intubated without difficulty, while maintaining cricoid pressure.

Intraoperatively, anesthesia was maintained with $70 \%$ nitrous oxide $\left(\mathrm{N}_{2} \mathrm{O}\right)$ in oxygen, and $0.6-0.8 \%$ end-tidal isoflurane. Neuromuscular blockade was monitored by measuring the contraction of the adductor pollicis with a M-NMT-S/5 mechanosensor (Datex-Ohmeda, Finland) after supramaximal stimulation of the ulnar nerve at the elbow in a train-of-four (TOF) pattern. After spontaneous recovery of the TOF ratio to 0.5 , and ten minutes after the initial dose of $\mathrm{SCh}$, rocuronium $\left(0.35 \mathrm{mg} \cdot \mathrm{kg}^{-1}\right)$ was administered for muscle relaxation. Neuromuscular blockade was subsequently maintained with incremental doses of $0.15 \mathrm{mg} \cdot \mathrm{kg}^{-1}$ or $0.2 \mathrm{mg} \cdot \mathrm{kg}^{-1}$ of rocuronium, whenever the first twitch of TOF stimulation ( $\mathrm{Tl}$ ) recovered to $25 \%$ of control value, for at least three successive stimulations (Table).

Fifty seconds after the initial dose of rocuronium, the first decrease in twitch amplitude was observed. Recovery of $\mathrm{Tl}$ to $25 \%$ of control took $15.3 \mathrm{~min}$. The
TABLE Dose, intensity and duration of rocuronium blockade

\begin{tabular}{llllllll}
\hline & \multicolumn{8}{c}{ Rocuronium dose (mg) } \\
& 30 & 15 & 15 & 20 & 20 & 20 & 20 \\
\hline $\begin{array}{l}\text { Tl at time of injection } \\
(\% \text { of control*) }\end{array}$ & 50 & 20 & 24 & 24 & 20 & 20 & 26 \\
$\begin{array}{l}\text { Maximum twitch suppression } \\
(\% \text { of control*) }\end{array}$ & 0 & 10 & 12 & 6 & 8 & 4 & 4 \\
†uration & 15.36 .3 & 5.5 & 10 & 9.5 & 10.3 & 10.5 \\
\hline
\end{tabular}

* Control value was obtained after the induction with propofol, and before administration of succinylcholine.

†Time from injection to the return of $\mathrm{Tl}$ to $25 \%$ of control in minutes.

average duration of $0.15 \mathrm{mg} \cdot \mathrm{kg}^{-1}$ incremental doses was $5.9 \mathrm{~min}$ and that of $0.2 \mathrm{mg} \cdot \mathrm{kg}^{-1}$ was ten minutes.

Heart rate, blood pressure, and body temperature were stable throughout the case. End-tidal $\mathrm{CO}_{2}$ was maintained between 32 and $36 \mathrm{mmHg}$. At the end of surgery, neuromuscular blockade was antagonized with $0.05 \mathrm{mg} \cdot \mathrm{kg}^{-1}$ of neostigmine and $0.01 \mathrm{mg} \cdot \mathrm{kg}^{-1}$ of glycopyrrolate. The trachea was extubated in the operating room. The patient was transported to the postanesthesia care unit without complication.

The patient was followed up in the endocrinology clinic at three weeks postsurgery. Ionized calcium levels were maintained within normal limits and PTH level decreased to $9.5 \mathrm{pg} \cdot \mathrm{mL}^{-1}$. The patient continues to do well postoperatively.

\section{Discussion}

A moderate increase in serum calcium level in the presence of increased PTH is the most valuable indicator for primary HPT. ${ }^{5}$ Hypercalcemia affects multiple organ systems and is responsible for the broad spectrum of signs and symptoms that accompany primary HPT. Skeletal muscle weakness with hypotonia is the most frequent complaint. ${ }^{5}$

Management of anesthesia depends on the preoperative serum calcium level and associated medical complications. Maintenance of perioperative hydration and urine output is important for management of hypercalcemia. ${ }^{1}$ It has been suggested that hypercalcemia associated with primary HPT may antagonize the effect of NDMRs. ${ }^{2,3}$ Hypercalcemia has also been shown to antagonize the neuromuscular blockade of NDMRs and SCh in vitro. ${ }^{4}$

Our patient presented with a medical history of hyperparathyroidism and had a subtotal parathyroidectomy nine months previously. Although it has been 
shown that a serum calcium level of $15 \mathrm{mg} \cdot \mathrm{dL}^{-1}$ or more antagonizes the effect of NDMRs, ${ }^{3}$ in this case, the serum calcium level was normal $\left(10.8 \mathrm{mg} \cdot \mathrm{dL}^{-1}\right)$.

Normally, repeat doses of rocuronium $(0.15$ $\left.\mathrm{mg} \cdot \mathrm{kg}^{-1}\right)$ administered to maintain relaxation during surgery provide a clinical duration of $13.4-18.3 \mathrm{~min} .{ }^{6}$ In this case, incremental doses of rocuronium resulted in average durations of $5.9 \mathrm{~min}$ with $0.15 \mathrm{mg} \cdot \mathrm{kg}^{-1}$, and ten minutes with $0.2 \mathrm{mg} \cdot \mathrm{kg}^{-1}$, which is considerably shorter than the expected duration of action of rocuronium. Prior administration of SCh does not appear to affect the potency of rocuronium. ${ }^{7}$ Isoflurane augments and prolongs the neuromuscular blockade of NDMRs, ${ }^{8}$ which was not apparent in this patient. Electrolytes, acid-base balance and temperature were within normal ranges, as were renal and liver function values, and, therefore, cannot explain the altered duration of rocuronium blockade.

The fact that the duration of rocuronium was reduced in our patient despite normal serum ionized calcium level suggests a second mechanism for a reduction in the duration of NDMRs in primary HPT, in addition to hypercalcemia. In an earlier study, patients with HPT seemed sensitive to all electromyographic procedures and were unable to tolerate repetitive nerve stimulation at supramaximal intensities. ${ }^{9}$ It has also been demonstrated that both type I and type II muscle fibres undergo atrophy in HPT, with type II fibres more extensively involved. ${ }^{9}$ Type II muscle fibre atrophy is neurogenic in origin suggesting that dysfunction is in the axon or in the motor neuron soma itself. ${ }^{9,10}$

The denervation of skeletal muscle fibres results in up-regulation of acetylcholine receptors (AChRs) at the neuromuscular junction as well as at extra-junctional sites. ${ }^{11} \mathrm{~A}$ well-established pharmacologic doctrine is that up-regulation of a receptor is associated with resistance (hyposensitivity) to competitive antagonists (e.g., NDMRs). ${ }^{12}$ The relationship of AChRs and neuromuscular relaxants has been confirmed in a number of studies where up-regulation of AChRs resulted in increased requirements for NDMRs. This association has been established with conditions which include burns, denervation, and the chronic administration of a muscle relaxant or an anticonvulsant drug. ${ }^{13-15} \mathrm{AChR}$ up-regulation has not been described with HPT; however, muscular disease in HPT appears to be neurogenic. ${ }^{16}$ This neurogenic muscular atrophy may result in up-regulation of AChRs and subsequent hyposensitivity to NDMRs. AChR up-regulation may also increase the risk of a hyperkalemic response from SCh use. ${ }^{12}$

This case shows that the response to rocuronium was reduced even in the presence of normal serum calcium level, in a patient with primary HPT and sug- gests that special attention should be paid to neuromuscular function monitoring in patients with HPT, regardless of serum calcium level. We speculate that up-regulation of AChRs may result from neurogenic myopathy of primary HPT and cause hyposensitivity to NDMRs. Further investigation is necessary to evaluate the presence and possible role of extra-junctional AChRs in patients with HPT.

\section{Acknowledgements}

We thank Dr. Michael L. Schmitz for reviewing a preliminary version of this report, and would like to acknowledge the helpful discussion and generous help in manuscript preparation by Dr. Sorin J. Brull.

\section{References}

1 Roizen M. Anesthetic implications of concurrent diseases. In: Miller R (Ed.). Anesthesia, 5 th ed. Philadelphia: Churchill Livingstone; 2000: 930-1.

2 Roland EJ, Wierda JM, Eurin BG, Roupie E. Pharmacodynamic behaviour of vecuronium in primary hyperparathyroidism. Can J Anaesth 1994; 41: 694-8.

3 Kirita A, Iwasaki H, Fujita S, Narimatsu H, Nishikawa $\Upsilon$, Namiki A. Vecuronium-induced neuromuscular blockade in two patients with hyperparathyroidism and a patient with hypoparathyroidism (Japanese). Masui 1992; 41: 136-9.

4 Okamoto T. Effects of magnesium and calcium on muscle contractility and neuromuscular blockade produced by muscle relaxants and aminoglycosides (Japanese). Masui 1992; 41: 1910-22.

5 Stoelting R, Dierdorf S. Endocrine disease. In: Stoelting R, Dierdorf S (Eds.). Anesthesia and CoExisting Disease, 3rd ed. Philadelphia: Churchill Livingstone; 1993: 355-6.

6 Lambalk LM, De Wit AP, Wierda JM, Hennis PJ, Agoston S. Dose-response relationship and time course of action of Org 9426. Anaesthesia 1991; 46: 907-11.

7 Cooper R, Mirakhur RK, Clarke RS, Boules Z. Comparison of intubating conditions after administration of Org 9246 (rocuronium) and suxamethonium. Br J Anaesth 1992; 69: 269-73.

8 Vanlinthout LE, Booij LH, van Egmond J, Robertson $E N$. Effect of isoflurane and sevoflurane on the magnitude and time course of neuromuscular block produced by vecuronium, pancuronium and atracurium. $\mathrm{Br} \mathrm{J}$ Anaesth 1996; 76: 389-95.

9 Patten BM, Bilezikian JP, Mallette LE, Prince A, Engel WK, Aurbach GD. Neuromuscular disease in primary hyperparathyroidism. Ann Intern Med 1974; 80: 182-93.

10 Engel WK. Classification of neuromuscular disorders. Birth Defects Orig Artic Ser 1971; 7: 18-37. 
11 Almon RR, Appel SH. Cholinergic sites in skeletal muscle. I. Denervation effects. Biochemistry 1976; 15 : 3662-7.

12 Martyn JA, White DA, Gronert GA, Jaffe RS, Ward $J M$. Up-and-down regulation of skeletal muscle acetylcholine receptors. Effects on neuromuscular blockers. Anesthesiology 1992; 76: 822-43.

13 Kim CS, Arnold FJ, Itani MS, Martyn JA. Decreased sensitivity to metocurine during long-term phenytoin therapy may be attributable to protein binding and acetylcholine receptor changes. Anesthesiology 1992; 77: 500-6.

14 Kim C, Martyn J, Fuke N. Burn injury to trunk of rat causes denervation-like responses in the gastrocnemius muscle. J Appl Physiol 1988; 65: 1745-51.

15 Hogue CW Jr, Itani MS, Martyn JA. Resistance to dtubocurarine in lower motor neuron injury is related to increased acetylcholine receptors at the neuromuscular junction. Anesthesiology 1990; 73: 703-9.

16 Ljunghall S, Akerstrom G, Johansson G, Olsson $\Upsilon$, Stalberg E. Neuromuscular involvement in primary hyperparathyroidism. J Neurol 1984; 231: 263-5.

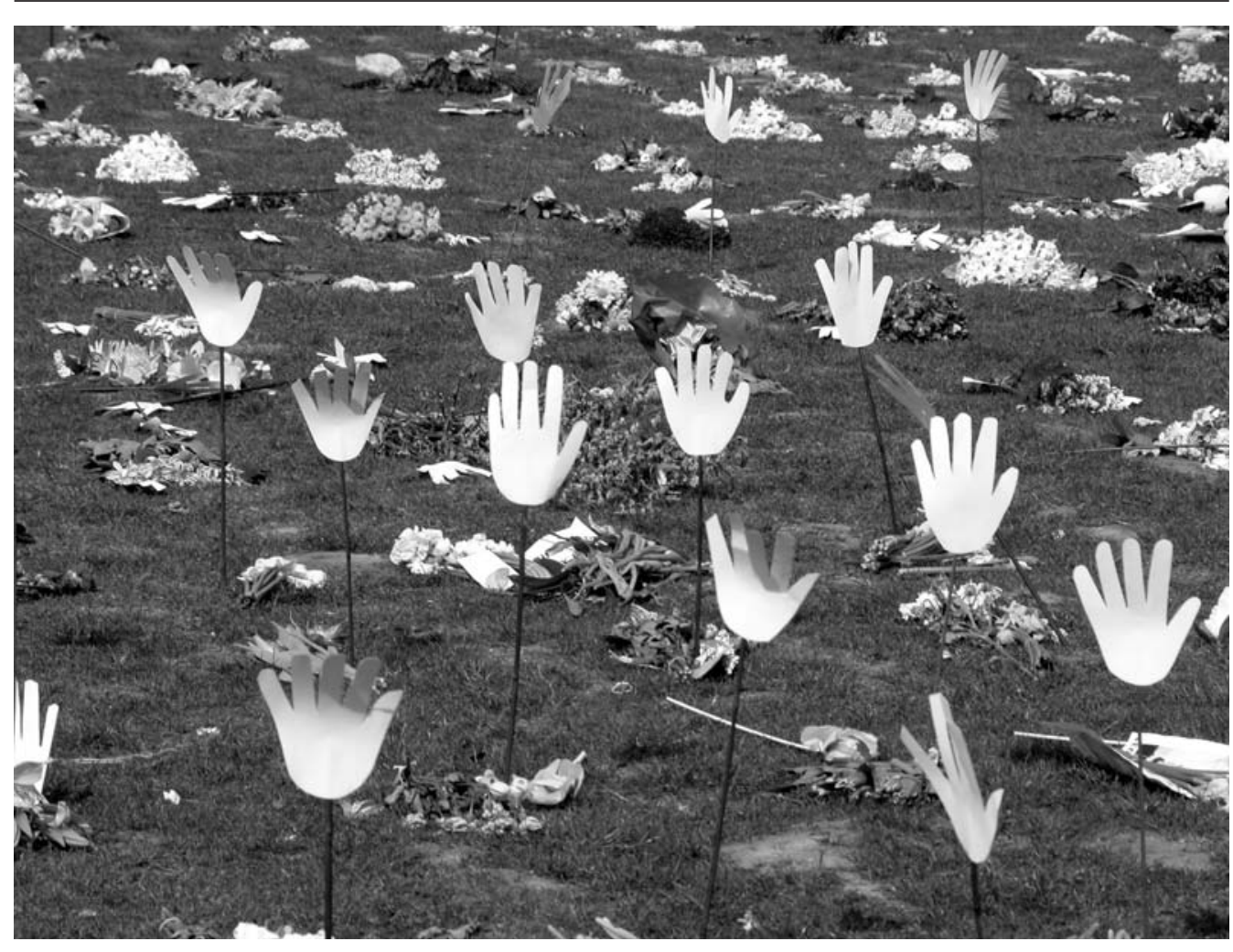

Peace protest - London, UK 